\title{
Gender Justice and Equality in Rice Farming Friendly Environment in Realizing Family Food Security
}

\author{
*Asih Mulyaningsih \\ *Department of Agribusiness, Faculty of \\ Agriculture \\ Sultan Ageng Tirtayasa \\ UniversityIndonesia Center of Execelenc \\ for Food Security (I-CEFORY), \\ UNTIRTA (Local Food Innovation) \\ Banten, Indonesia \\ *asihmulya@ymail.com
}

\author{
Suherna \\ Department of Agribusiness, Faculty of \\ Agriculture \\ Sultan Ageng Tirtayasa University \\ Indonesia Center of Execelenc for Food \\ Security (I-CEFORY), UNTIRTA (Local \\ Food Innovation), \\ Banten, Indonesia \\ shsuherna@yahoo.com
}

\author{
Gugun Gunawan \\ Department of Agribusiness, Faculty of \\ Agriculture \\ Sultan Ageng Tirtayasa University \\ Banten, Indonesia \\ gugungu73@gmail.com
}

\begin{abstract}
The purpose of this study was to analyze justice and gender equality in environmentally friendly lowland rice farming in realizing family food security in Banten Province. The research method is a survey with research design is descriptive that takes samples in one population using questionnaires as a data collection tool. The study was conducted for three months from April to June 2019. The research sites were in three districts in Banten Province, namely Serang Regency, Pandeglang Regency, and Lebak Regency. The number of samples in the study were 160 lowland rice farmer families (husband and wife). Data analysis uses gender equality and equity indexes. The results showed that access and control in farming activities were dominated by male farmers such as: land management, fertilization, pest and disease control, and marketing was dominated by male farmers while female farmers dominated in the nursery and maintenance stages. Planting and harvesting is done jointly between male and female farmers. Here we see the division of labor between male farmers and female farmers, where male farmers work on farming activities that rely on physical strength while female farmers get a division of labor that requires perseverance such as nursery and maintenance. The conclusion is that to realize justice and gender equality of ecofriendly rice farmers to achieve sustainable food security, of course, it must be supported by all parties, both government and farmers.
\end{abstract}

Keywords: justice, equality, gender, rice, food

\section{INTRODUCTION}

Many gender issues are found in agriculture related to access to opportunities and opportunities, participation in decision-making processes, control of resources, and the acquisition of benefits from development outcomes. For agricultural land resources, generally men and women who work as farmers have equal access to opportunities and opportunities, participation in agricultural land. While those who control generally are men, because the land certificate is in the name of the husband.

Lowland rice farming requires technology to help carry out its activities, including in agriculture. The technology used can be as simple as ani-ani and sickle and modern technology (tractors). In general, men access more modern technology, while women use more simple technology. This is related to the quality of human resources, where generally the education level of women is still low, making it difficult to access technology [7]. According to [9] in the implementation of rice farming starting from the stages of land management, planting to harvesting results enabled the absorption of male and female workers. The existence of a community culture that places women in a certain perspective results in the occurrence of gender bias in rice farming activities.

Processing of agricultural land is dominated by only male workers, as well as weeding and fertilization involving male labor. This situation is based on an understanding of a stronger male workforce, so it is very appropriate for the need to hoe or operate a tractor. Likewise, for weeding and fertilizing work which assumes that men have more speed and agility so that the work is expected to be more quickly resolved by men. Conversely, planting and harvesting activities are dominated by female workers. According to [3], the Green Revolution program in Java which introduced superior types of rice that grew lower, and a harvest approach with a system of harvesting using sickles, did not allow the use of ani-ani, the entry of hullers also shifted the role traditional women as paddy farmers. As a result, many female farmers are marginalized. The traditional participation of female farmers as workers in the paddy fields was eliminated, meaning that the green revolution program was designed without taking into account the gender apprehension of women.

The lack of involvement of women often results in the proposals being produced less favoring women. Gender Mainstreaming is a strategy built to integrate gender into an integral dimension of planning, drafting, implementing, monitoring and evaluating national development policies and programs. By organizing gender mainstreaming, it can be identified whether agriculture is gender responsive from aspects: 1) obtaining equal access to development resources, 2) having the same opportunity to participate in the development process, especially in the decision-making process; 3) have the same control over development resources, and 4) obtain the same benefits for the results of development. Therefore, this study emphasizes justice and gender equality in wetland rice farming in support of family 
food security. Analysis of gender equality and equality in rice farming is expected to be an input for policy makers in agriculture. Various previous studies [1], [2], [5], [8], [4], [12], reviewed the empowerment of farmers. This study seeks to complement previous studies, by examining the fairness and gender equality of lowland rice farmers in supporting family food security.

\section{METHODS}

This research was designed using a quantitative approach supported by data and qualitative analysis. Procedures or ways to collect data and information using the survey method from a number of respondents with a questionnaire guide. The research was carried out in three paddy center districts in Banten Province, namely Serang Regency, Pandeglang Regency, and Lebak Regency for three months from April to June 2019. The population in this study were families of lowland rice farmers (husbands and wives) spread across three districts with the number of respondents 160 households (husband and wife). Data analysis uses a pattern of gender relations quantitatively shown in the form of Gender Equity and Justice Index figures (IKKG). According to [6], IKKG for certain characteristics greater than one (IKKG> 1) shows there is gender inequality (gap) where the proportion of women in these characteristics is greater than the proportion of men in the same characteristics. Conversely, if the IKKG values for certain characteristics are smaller than one (IKKG <1) indicates there are gender inequalities where the proportion of women in these characteristics is smaller than the proportion of men in the same characteristics. Equality and gender justice occur if IKKG is worth one. In order to facilitate the classification of the level of gender relations in each farming pattern in the aspects of access and control of resources and the standard stages of farming activities are used as presented in Table 1.

TABLE I. EQUALITY AND GENDER JUSTICE, CLASSIFICATION, AND SYMBOLS OF THE PATTERN OF THE RELATIONSHIP BETWEEN MEN AND WOMEN FARMERS

\begin{tabular}{l|l|l|l}
\hline No. & Equality and Gender Justice & \multicolumn{1}{|c}{ Classification } & Symbol \\
\hline 1. & $0.00>$ IKKG $\leqslant 0.50$ & Dominant male & DL \\
2. & $0.50>$ IKKG $\leqslant 1.00$ & Together & BS \\
3. & \multicolumn{1}{|c|}{ IKKG $>1.00$} & Dominant Woment & DP \\
\hline
\end{tabular}

The pattern of gender relations in each farming pattern in Karanganyar Regency is seen from the level of access and control of men and women to the resources owned and the stages of farming activities carried out. To measure the level of access and control in each farming pattern in the study location 15 variables were used.

\section{RESULT AND DISCUSSION}

The pattern of gender relations in lowland rice farming in this study was seen from the access and control of male farmers and female farmers (husband and wife) in managing wetland rice farming. The pattern of gender relations is quantitatively expressed in the form of numbers. The pattern of gender relations in wetland rice farming is generally dominated by male farmers.

Based on the results of the FGD in farmer groups in the three districts in Banten Province, an overview of male and female farmers in allocating available resources, overcoming problems, finding solutions, and the level of access and control of the resources owned and the stages of farming carried out. In detail the description of the conditions of farmers and women in farming activities in the following three districts.

TABLE II. OPINIONS OF MALE AND FEMALE FARMERS ABOUT FARMING PATTERNS.

\begin{tabular}{|c|c|c|}
\hline Pattern of farming & $\begin{array}{l}\text { Female } \\
\text { farmers }\end{array}$ & $\begin{array}{c}\text { Male } \\
\text { farmers }\end{array}$ \\
\hline \multicolumn{3}{|l|}{ 1. Problems faced } \\
\hline a. Scarcity of fertilizer & Yes & Yes \\
\hline b. Water scarcity & Yes & Yes \\
\hline c. Marketing of agricultural products & Yes & Yes \\
\hline d. Timely pest control & Yes & Yes \\
\hline $\begin{array}{l}\text { e. Problems with guarantees for capital } \\
\text { lending }\end{array}$ & Yes & Yes \\
\hline \multicolumn{3}{|l|}{ 2. The solution that will ever be done } \\
\hline $\begin{array}{l}\text { a. The scarcity of fertilizer is overcome by } \\
\text { farm cards }\end{array}$ & Yes & No \\
\hline $\begin{array}{l}\text { b. To overcome water scarcity by building } \\
\text { irrigation }\end{array}$ & Yes & No \\
\hline \multicolumn{3}{|l|}{ 3. Access and control of } \\
\hline a. Tillage & Yes & No \\
\hline b. Pricing of farm produce & Yes & No \\
\hline c. Marketing & Yes & No \\
\hline d. Harvest & Yes & No \\
\hline e. Drying rice & Yes & No \\
\hline
\end{tabular}

The Focus Group Discussion results show that male farmers and female farmers have the same problems, namely the problem of fertilizer scarcity, water scarcity, marketing of agricultural products, inaccurate pest control, and guarantee issues for borrowing capital. For male farmers, they have the ability to think of solutions faced and even know what steps to take to deal with the problem, while female farmers do not provide answers to solve problems faced in managing their farming. This is due to the limited knowledge and insight of female farmers in farming, because female farmers are less involved in the management activities of farmer groups and counseling. In addition, female farmers always follow what has been decided by their husbands (male farmers). In addition, the activities of female farmers in managing farming are still limited to helping male farmers and implementing what has been decided by the husband (male farmer) in managing their farming. This shows the strong culture of Patriarchy in the three districts in Banten Province, where generally wives (female farmers) are generally rarely involved in making decisions in the management of farming.

TABLE III. ACCESS AND CONTROL OF MALE AND FEMALE ON RESOURCES AND STAGES OF RICE FARMING ACTIVITIES

\begin{tabular}{lcccc}
\hline \multirow{2}{*}{$\begin{array}{l}\text { Resources and stages of rice } \\
\text { farming activities }\end{array}$} & \multicolumn{4}{c}{ Access } \\
\cline { 2 - 5 } & \multicolumn{2}{c}{ Male farmers } & \multicolumn{2}{c}{ Female farmers } \\
\cline { 2 - 5 } Resource & $\mathrm{L}(\%)$ & $\mathrm{P}(\%)$ & $\mathrm{L}(\%)$ & $\mathrm{P}(\%)$ \\
\hline Extension & 78,24 & 21,76 & 70,37 & 29,63 \\
\hline Education & 75,00 & 25,00 & 69,44 & 30,56 \\
\hline Harvest proceeds & 69,91 & 30,09 & 67,13 & 32,87 \\
\hline Capital & 73,15 & 26,85 & 66,67 & 33,33 \\
\hline Credit & 76,39 & 23,61 & 75,93 & 23,61 \\
\hline Equipment & 79,63 & 20,37 & 74,54 & 25,46 \\
\hline Information & 66,20 & 33,80 & 58,80 & 41,20 \\
\hline Stages of Activity & \multicolumn{3}{c}{} & \\
\hline Land processing & 93,52 & 6,48 & 90,74 & 9,26 \\
\hline Nursery & 42,59 & 57,41 & 39,35 & 60,65 \\
\hline
\end{tabular}




\begin{tabular}{|c|c|c|c|c|}
\hline Planting & 55,09 & 44,91 & 51,85 & 48,15 \\
\hline Fertilization & 92,13 & 7,87 & 89,81 & 10,19 \\
\hline Maintenance & 80,56 & 19,44 & 72,22 & 27,78 \\
\hline Disease control & 87,96 & 12,04 & 79,63 & 20,37 \\
\hline Harvest & 77,31 & 22,69 & 72,69 & 27,31 \\
\hline Marketing & 76,39 & 23,61 & 68,52 & 31,48 \\
\hline \multirow{3}{*}{$\begin{array}{l}\text { Resources and stages of } \\
\text { rice farming activities }\end{array}$} & \multicolumn{4}{|c|}{ Control } \\
\hline & \multicolumn{2}{|c|}{ Male farmers } & \multicolumn{2}{|c|}{ Female farmers } \\
\hline & $\mathrm{L}(\%)$ & $\mathrm{P}(\%)$ & $\mathrm{L}(\%)$ & $\mathrm{P}(\%)$ \\
\hline \multicolumn{5}{|l|}{ Resource } \\
\hline Extension & 56,94 & 43,52 & 43,98 & 56,02 \\
\hline Education & 73,15 & 26,85 & 70,37 & 29,63 \\
\hline Harvest proceeds & 68,98 & 31,02 & 67,59 & 32,41 \\
\hline Capital & 82,41 & 17,59 & 75,46 & 24,54 \\
\hline Credit & 81,94 & 18,06 & 74,54 & 25,46 \\
\hline Equipment & 81,02 & 18,98 & 81,94 & 18,06 \\
\hline Information & 85,65 & 14,35 & 83,80 & 16,20 \\
\hline \multicolumn{5}{|l|}{ Stages of Activity } \\
\hline Land processing & 67,13 & 32,87 & 63,43 & 36,57 \\
\hline Nursery & 49,54 & 50,46 & 49,54 & 50,06 \\
\hline Planting & 54,17 & 45,83 & 51,39 & 48,61 \\
\hline Fertilization & 69,44 & 30,56 & 56,48 & 43,52 \\
\hline Maintenance & 49,54 & 50,06 & 47,22 & 52,78 \\
\hline Disease control & 77,31 & 22,69 & 73,61 & 26,39 \\
\hline Harvest & 56,94 & 43,06 & 54,63 & 45,37 \\
\hline Marketing & 71,76 & 28,24 & 71,76 & 28,24 \\
\hline
\end{tabular}

Access and control in farming activities were dominated by male farmers such as: land management, planting, fertilizing, maintenance, pest control and disease, harvesting, and marketing dominated by male farmers while female farmers dominated the nursery stage. Here is the division of labor between male farmers and female farmers, where male farmers work on farming activities that rely on physical strength while female farmers get a division of labor that requires perseverance such as nursery and maintenance.

The index of gender equality and justice (IKKG) shows the pattern of gender relations in wetland farming in terms of control over resources and the stage of activity, dominated by male farmers. Activities involving farmer resources are dominated by male farmers both in terms of access and control, in terms of farmer participation in extension activities, education, access to harvest sales, access to capital, access to credit, use of agricultural equipment, and information from the media. . The pattern of relations at the stage of farming activities in the aspect of access is dominated by male farmers for land processing, fertilization, eradication of pests and diseases, harvesting and marketing. Female farmers are more dominant in nursery and maintenance activities, so that planting activities are carried out jointly between male farmers and female farmers.

TABLE IV. GENDER EQUALITY AND JUSTICE INDEX ON ASPECTS OF ACCESS AND CONTROL IN WETLAND RICE FARMING

\begin{tabular}{lllll}
\hline \multirow{2}{*}{$\begin{array}{l}\text { Resources and stages of } \\
\text { rice farming activities }\end{array}$} & \multicolumn{2}{c}{ Access } & \multicolumn{2}{c}{ Control } \\
\cline { 2 - 5 } Resource & IKKG & Category & IKKG & Category \\
\hline Extension & 0,12 & DL & 0,17 & DL \\
\hline Education & 0,15 & DL & 0,15 & DL \\
\hline Harvest proceeds & 0,21 & DL & 0,22 & DL \\
\hline Capital & 0,19 & DL & 0,07 & DL \\
\hline Credit & 0,10 & DL & 0,08 & DL \\
\hline Equipment & 0,09 & DL & 0,05 & DL \\
\hline Information/Media & 0,36 & DL & 0,03 & DL \\
\hline Stages of Activity & & & & \\
\hline Land processing & 0,01 & DL & 0,28 & DL \\
\hline Nursery & 2,06 & DP & 1,03 & DP \\
\hline
\end{tabular}

\begin{tabular}{lllll}
\hline Planting & 0,75 & BS & 0,80 & BS \\
\hline Fertilization & 0,01 & DL & 0,35 & DL \\
\hline Maintenance & 1,08 & DP & 1,13 & DP \\
\hline Disease control & 0,04 & DL & 0,11 & DL \\
\hline Harvest & 0,11 & DL & 0,63 & BS \\
\hline Marketing & 0,15 & DL & 0,15 & DL \\
\hline $\begin{array}{l}\text { Note: Value } 0.00>\text { IKKG } \leq 0.5 \text { Dominant male (DL); } 0.5>\text { IKKG } \leq 1 \text { Together (BS); } \\
\text { IKKG }>1 \text { Dominant Female (DP) }\end{array}$ & & & &
\end{tabular}

The index of gender equality and justice (IKKG) shows the pattern of gender relations in wetland farming in terms of control over resources and the stage of activity, dominated by male farmers. Activities involving farmer resources are dominated by male farmers both in terms of access and control, in terms of farmer participation in extension activities, education, access to harvest sales, access to capital, access to credit, use of agricultural equipment, and information from the media. . The pattern of relations at the stage of farming activities in the aspect of access is dominated by male farmers for land processing, fertilization, eradication of pests and diseases, harvesting and marketing. Female farmers are more dominant in nursery and maintenance activities, so that planting activities are carried out jointly between male farmers and female farmers.

Gender equality can be improved on lowland rice farming by increasing the role of women in aspects of control over resources and on farming activities. According to [10] when viewed from the outpouring of work time, the average woman plays a very important role in agricultural activities, especially in the production subsystem. The role of women in the agricultural sector has lasted a long time and is seen as something natural. The gap between male farmers and female farmers occurs, because generally resource control and activity stages are dominated by male farmers.

Gender equality can be realized, in broad outline there are two forms of policy directives that are needed namely: increasing the role of men in seedling planting, and increasing women's role in processing agricultural land, using tractors, credit, and agricultural capital, farming information, being involved in management farmer groups, land management, and fertilization.

TABLE V. FORMULA FOR POLICY DIRECTION BASED ON THE CONDITION OF GENDER RELATIONS ASPECTS OF THE STAGES OF RICE FARMING ACTIVITIES.

\begin{tabular}{lccc}
\hline $\begin{array}{l}\text { Variable policy } \\
\text { direction }\end{array}$ & $\begin{array}{l}\text { Present } \\
\text { condition }\end{array}$ & Internal & External \\
\hline Extension & DL-DL & $\sqrt{ }$ \\
\hline Education & DL-DL & $\sqrt{ }$ \\
\hline Harvest proceeds & DL-DL & $\sqrt{ }$ \\
\hline Capital & DL-DL & $\sqrt{ }$ \\
\hline Credit & DL-DL & $\sqrt{ }$ \\
\hline Equipment & DL-DL & & \\
\hline Information / media & DL-DL & $\sqrt{ }$ \\
\hline Land processing & DL-DL & $\sqrt{ }$ & \\
\hline Nursery & DP-DP & $\sqrt{ }$ & \\
\hline Planting & BS-BS & $\sqrt{ }$ \\
\hline Fertilization & DL-DL & $\sqrt{ }$ \\
\hline Maintenance & DP-DP & $\sqrt{ }$ \\
\hline Disease control & DL-DL & $\sqrt{ }$ \\
\hline Harvest & DL-BS & \\
\hline Marketing & DL-DL & \\
\hline
\end{tabular}

Taking into account the central role of women in various agricultural activities, women must be given equal opportunities with men to gain access to land and other 
resources, such as: credit, technology and knowledge [13]. According to [11], there are still symptoms that indicate gender injustice and discrimination in agriculture. Increasing the role of women at this stage should not cause the workload and outflow of time when female farmers become larger. Counseling and training need to be done for male and female farmers, so that male farmers will increasingly understand that as men and the head of the household also must and want to do domestic work namely household affairs. If this is understood by male farmers, then the time spent by female farmers in domestic activities will be reduced and can be channeled to productive activities. Thus the double burden of a wife so far will eventually be reduced and can even be lost and finally there is no gender gap at the level of the farmer household.

In general, in the field it was found that in the management of rice paddy farming, the role of male farmers was more dominant. The husband who was conditioned as the head of the household and supported by a thick patriarchal culture in the Banten community, caused his wife to fully work to help her husband. This is a condition that supports the dominance of control from husbands towards wives in rice farming activities.

In general, the use of rice paddy farming is dominated by male farmers. The pattern of relations on rice paddy farming can be improved by increasing the role of women in aspects of agricultural land use, utilization of irrigation channels, utilization of information on extension information, and farming technology. The male farmers who need to be improved are utilizing their farming results. Participation in the cultivation of rice paddy plants is mostly done by female farmers. Generally female farmers are less involved in eradicating plant disease pests because female farmers are not involved in counseling eradication of plant pests and diseases. Fertilization activities are usually carried out by male farmers and female farmers are less involved in fertilizing for rice farming. Generally male farmers determine the timing of harvesting of paddy fields and female farmers help their husbands to harvest lowland rice. Management of agricultural land is generally carried out by male farmers. Processing land for the preparation of planting rice. Land processing usually uses hoes, plowing tools with the help of buffaloes, and tractors carried out by male farmers.

Improvements to the aspects of access and control on rice paddy farming in order to realize gender equality in farm households, intervention from outside parties (government) is needed based on the conditions of the pattern of gender relations aimed at IKKG values. At the IKKG value, which includes the dominant male classification (DL), the policy needed is an effort to increase the role of women in aspects of access, and control. Broadly speaking, there are two forms of policy direction needed, namely: increasing access and control to female farmers on agricultural land tenure, using tractors, credit and agricultural capital, farming information, management of farmer groups, land processing, fertilization, harvesting, present at counseling, harvest time, type of variety planted, selling agricultural products, amount of crops sold, dosage of fertilizer used, control of plant pest organisms (OPT), utilizing agricultural land, irrigation channels, extension services, and agricultural technology, participating in eradication plant pests and diseases, fertilization, harvesting, management of agricultural land. The role of men needs to be improved in the aspect of planting rice paddy seeds.

\section{CONCLUSION}

In this case gender equality and justice have not been equal between male farmers and female farmers. The Gender Equality and Equality Index is still dominated by male farmers in activities involving resources for farming activities, namely: land management, fertilization, pest and disease control, harvesting and marketing. Female farmers dominate nursery and harvesting activities while planting activities are carried out jointly between male and female farmers

\section{RECOMMENDATION}

Gender equality can be realized, in broad outline there are two forms of policy directives that are needed, namely: increasing the role of women in land management, fertilization, pest and disease control, harvesting and marketing and increasing the role of men in nurseries and harvesting, and involving female farmers in management of farmer groups

\section{REFERENCES}

[1] Aminah S, Sumardjo, Lubis DP, Susanto D. 2015. Factor affecting peasants empowerment in West Halmahera District. A case study from Indonesia. J. Agriculture and Rural Development in the Tropics and Subtropics. 116 (1): 1-15.

[2] Astuti M. 2012. Pemberdayaan perempuan miskin perspektif pemanfaatan sumber daya lokal melalui pendekatan sosial entrepreneurship. J. Sosiokonsepsia. 17 (3): 241-251.

[3] Fakih M. 2008. Analisis Gender Transformasi Sosial, Yogyakarta: INSISTPress.

[4] Hakim L,Sugihen BG. 2007. Pemberdayaanpetanisayuran: kasuspetanisayuran di Sulawesi Selatan.JurnalPenyuluhan, 3(1): 4554.

[5] Hishiyama R. 2013. Sustainable empowerment models for rural pastoral communities in Kenya. J Sage. 85(1): 432-442 [diunduh 12 januari 2017]. Tersedia pada: http//www.sciencedirect.com.

[6] KPP, 2001. Bunga Rampai Bahan Pembelajaran Pelatihan Pengarusutamaan gender Bidang Kesehatan Reproduksi \& Kependudukan. Kementerian Pemberdayaan Perempuan, BKKBN, dan UNFPA. Jakarta

[7] Novia, Dina, 2006. Analisis Sosial Ekonomi Terhadap Peran Perempuan Pedesaan Di Dalam Keluarga Dan Masyarakat Di Desa Mangunrejo Kecamatan Kepanjen Kabupaten Malang.Tesis Program Studi Sosiologi Pedesaan. Program Pasca Sarjana. Universitas Brawijaya. Malang.

[8] Prijana. 2015. Model pemberdayaan masyarakat lokal. J. Komunikasi dan Informasi . 4(1): 146-151.

[9] Priyadi, Unggul, 2005. Tingkat Kesetaraan Gender Pada Usaha tani Padi Di Kecamatan Mlati Kabupaten Sleman. Available online with up dates at www.data.dppm.uii.ac.id. Verified 2 November 2016).

[10] Safar M. 2006. Diferensiasiperangender dan pengaruhbudayadalamaktivitaspertanian di perdesaanstudi di KecamatanPondidahaKabupatenKonaweProvinsi Sulawesi Tenggara. JurnalSelami IPS. 19(1): 21-30.

[11] Supriyati. 2006. Analisis gender di daerah pengembangan usahatani lahan pantai Kabupaten Kulon Progo. Jurnal Agro Ekonomi 13(1): 181-190.

[12] Tohidi H, Jabbari MM. 2011. The aspects of empowerment of human resources J. Proced. 31 (2011): 829-833. [diunduh 12 Desember 2016]. Tersedia pada: http//www.sciencedirect.com.

[13] Wahyuni ES.2007. Perempuanpetani dan penanggulangankemiskinan. JurnalAgrimedia. 12(1): 70-81. 